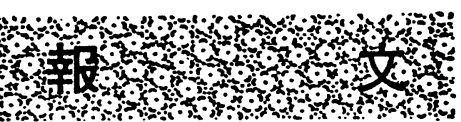

\title{
食品中のエンテロトキシン産生性黄色ブドウ球菌の 迅速簡易検査法*
}

(昭和 60 年 1 月 25 日受理)

小田隆弘 ${ }^{* 2 * 3}$

\section{Rapid and Simplified Detection Method for Enterotoxin-producing Staphylococcus aureus in Food}

\author{
Takahiro ODA \\ (Fukuoka Municipal Institute of Food Sanitation Inspection: \\ 6-23-1, Naka, Hakata-ku, Fukuoka, Japan)
}

\begin{abstract}
A rapid and simplified detection method for enterotoxin-producing Staphylococus aureus in food was devised. The procedure is as follows: a homogenized food sample is added to Tellulite-Lithium-Starch-Pyruvate Brain Heart Infusion broth in a Petri dish, and incubated for $18 \mathrm{hrs}$ at $37^{\circ} \mathrm{C}$. Enterotoxins produced in the broth are detected by using a "SET-RPLA" kit (Reversed Passive Latex Agglutination method).

Numerous bacteria coexisting with $S$. aureus in raw milk, minced meat and potato salad did not interfere with the growth and enterotoxin production of $S$. aureus. Egg-yolk reaction-negative $S$. aureus was also detected. An excellent correlation in bacterial count of $S$. aureus was found between MPN value obtained by the above procedure and the usual plate count. When this method was applied to various commercial foods, S. aureus was detected more effectively than by the conventional plate method.

This method may be useful for routine laboratory tests for the detection of $S$. aureus in foods.
\end{abstract}

(Received January 25, 1985)

Key words: 黄色ブドウ球菌 Staphylococcus aureus; エンテロトキシン enterotoxin; 増菌培養液 enrichment medium; 逆受身ラテックス凝集反応法 reversed passive latex agglutination method; 迅速簡易検出法 rapid simplified detection method

はじめに

食品衛生検查指針1)などで示されている黄色ブドウ球

*1 ブドウ球菌エンテロトキシン簡易検出法の応用に 関する研究（第 2 報）

*2 福岡市食品衛生検查所：福岡市博多区那珂 6-231 青果市場内

*3 現勤務先 福岡市衛生試験所：福岡市中央区舞 鶴 2-5-10
菌（以下 黄色ブ菌と略）検査は, 卵黄加マンニット食 塩培地などの平板培地上で即黄反応陽珄のブ菌様コロニ 一を検索し，その菌のコアグラーゼ産生能試験などによ り確認する.この場合, 卵黄反応陰性もしくはコアグラ 一ゼ微弱産生株は見落される可能性があり, 逆に, コア グラーゼ産生非黄色ブ菌 ${ }^{2)}$ を誤認することも予想され る. 従って, 著者は, 食中毒原性黄色ブ菌の鑑別には, その直接的性状であるェンテロトキシン（以下 ET と 
略）産生性により同定する方が妥当と考え, ET 産生性 を簡易に調べる方法として平板パンチ法を前報 ${ }^{3)}$ で報告 した.しかし，この方法でも，平板培地上にコロニーが 形成されるまで培養する必要があるため, 食品の ET 産 生黄色ブ菌検査法としては迅速性にやや欠ける.

そこで著者は, 食品から ET 産生黄色ブ菌の検出をさ らに迅速に行ら方法として, 食品中に含まれる黄色ブ菌 を選択増菌培地で培養し, 培養液中に産生される ETを 特異的に検出する簡易検査法を検討した.

\section{実 験方 法}

\section{ET 産生用增菌培地}

黄色ブ菌以外の細菌が多い食品でも，その中に含まれ る黄色ブ菌を選択的に増菌させ，ET を産生させる増菌 培地として, Baird-Parker 培地の組成を参考にし た Tellulite-Lithium-Starch-Pyruvate-Brain Heart Infusion Broth（以下 TLSP ブイヨンと略）を試作し て用いた。本培地の調製法は次のとおりである.ブレイ ンハートインフュージョン ブイョン (栄研化学(株)) を $1 \mathrm{~L}$ の精製水に処方通り溶解し，塩化りチウム $5 \mathrm{~g}$, 可溶性デンプン $10 \mathrm{~g}$ ，ピルビン酸ナトリウム $10 \mathrm{~g}$ を加 え, $121^{\circ}, 15$ 分間隇菌後, デンプンが底部で固まらない ように振りまぜながら泠却し, 亜テルル酸カリウム (Difco) $1 \%$ 液を $3 \mathrm{ml}$ (最終濃度として $0.003 \%$ 量) 加 えた. 覀テルル酸カリウムを加えたブイヨンは保存中に 選択性が低下したので，その都度調製した。

\section{2. 細菌数測定}

平板法によるブ菌数の測定には, 卵黄加マンニット食 塩培地を用い，ブ菌様コロニーを卵黄反応陽性コロニー と陰性コロニーに区別して算定した．生菌数及び大腸菌 群の測定は，それぞれ標準寒天（栄研）またはデスオキ シコレイト培地（栄研）を用い常法1)通りに行った。

\section{3. 供試黄色ブ菌}

食品への黄色ブ菌接種実験の場合は，食品由来保存株 F 85 及び F 93 の 2 菌株を用いた。これらは卵黄反応陽 性, コアグラーゼ型は II 及び VII 型, ET 型はそれぞ れ $\mathrm{AD}, \mathrm{BC}$ 型であった。

\section{4. 食品材料}

基礎的検討には，黄色ブ菌以外の細菌が多い食品とし て, 生乳, 市販生肉ミンチ及び収去検査で細菌数が多か った市販ポテトサラダを用いた.いずれも，実験に供す るまで凍結して保存した。

市販食品への応用実験では，市販の弁当類（にぎりめ し，寿司弁当など） 24 件，サラダ類15件，和洋生菓子 15 件，魚肉敉り製品（天ぷらかまぼこなど）13件，冷凍食 品（凍結前末加熱品） 4 件及びゆでめん 5 件の計76件を 用いた。

\section{5. 增菌培泰液中の ET 検出法}

液状食品はその $1 \mathrm{ml}$ を $15 \mathrm{ml}$ の TLSP ブイヨンに, 固型食品は, その10倍ホモジナイズ液 $10 \mathrm{ml}$ を倍濃度
の TLSP ブイヨン $10 \mathrm{ml}$ に加え, よく混和後, $37^{\circ}$ で 静置培養した。一定時間培養後, 培養液の上澄液もしく は遠心 (3,500 rpm 10分) 上清をとり，その中に含をれ る ET を逆受身ラテックス凝集反応法 (RPLA) により 検出した. ET A 〜 の 検出には, SET-RPLA キット (デンカ生研）と自製ラテックス試薬尔を，ET D の検出 には自製試薬のみを用いた，培養液中の ET 濃度を測定 する実験を除いては，培養上清 1 滴 (約 $0.03 \mathrm{ml}$ ) を，キ ットに添付されている $0.5 \%$ ウシ血清アルブミン加リ ン酸緩衝液にさらに正常ウサギ血清（デンカ生研）を $1 \%$ 量加えて調製した希釈液 $0.25 \mathrm{ml}$ に加えて約 10 倍 希釈液を作り，その希釈液についてマイクロプレート上 で ET A〜D の検出を行った.

\section{MPN 法による菌数測定}

被験材料の10倍ホモジナイズ液の原液, 10倍希釈液, 100 倍希釈液について, 各段階希釈液の $1 \mathrm{ml}$ ずつをそ れぞれ 3 本の TLSP ブイヨンに接種して一定時間培着 後, その培養上清について ET 検出を行った. ET が検 出された各希釈段階の陽性数から，MPN 表”により被 験材料に含まれた ET 産生黄色ブ菌数を MPN 值とし て求めた.

\section{7. 分離菌株の ET 及びコアグラーゼ産生能の確認}

増菌培養液から ET が検出された場合には，その 1 白 金耳を Baird-Parker 培地に塗抹培養し, 黄色ブ菌様独

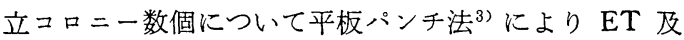
びコアグラーゼ産生能を確認した。

\section{成 䋶}

\section{TLSP ブイヨンにおける黄色ブ菌の增殖と ET 産} 生

黄色ブ菌以外の細菌が多い検体として生乳を用い，そ の中に含まれる ET 産生黄色ブ菌の TLSP ブイョンに おける増殖と ET 産生について調べた。

生乳 $1 \mathrm{ml}$ ずつを TLSP ブイ た中試験管 $(18 \times 180 \mathrm{~mm})$ とシャーレ（内径 $9 \mathrm{~cm}$ : 深さ $2 \mathrm{~cm}$ ) に加え， $37^{\circ}$ で静置培着したときの細菌数の 変化と ET 産生状況を Fig. 1 に示した.

生乳をブイヨンに投入した直後の生菌数は $2 \times 10^{5} / \mathrm{ml}$, 大腸菌群数 $8 \times 10^{2} / \mathrm{ml}$, 卵黄反応陽性ブ菌数 $8 \times 10^{2} / \mathrm{ml}$, 同陰性ブ菌数 $9 \times 10^{4} / \mathrm{ml}$ であったが，培養に伴い，中試 験管内培養またはシャーレ内培養を問わず，生菌数及び 卵黄反応陽性または陰性ブ菌数の急激な増加と大腸菌群 数の急速な減少がみられた. 中試験管内培養とシャーレ 内培養の間には, 菌の增殖態度に明らかな差は認められ なかった。しかし，ET 産生には顕著な差が認められ， シャーレ内培養では短時間のうちに多量の ET が検出 れさたが，中試験管内培養では同濃度の ET 産生量がみ られるのに長時間を必要とした， $37^{\circ} ， 18$ 時間培養の時 点で産生された ET 濃度を比較すると, シャーレ内培養 の方が中試験管内培養よりも約10倍高い値を示した. 
Table 1. Growth and Enterotoxin Production in TLSP Broth of S. aureus Inoculated to Minced Meat and to Potato Salad on Petri-dish Culture

\begin{tabular}{|c|c|c|c|c|}
\hline \multirow{3}{*}{$\begin{array}{c}\text { Bacterial counts }(/ \mathrm{ml}) \\
\text { or Enterotoxin conc. }(\mathrm{ng} / \mathrm{ml})\end{array}$} & \multicolumn{4}{|c|}{ Food samples $S$. aureus inoculated } \\
\hline & \multicolumn{2}{|c|}{ Minced meat } & \multicolumn{2}{|c|}{ Potato salad } \\
\hline & $0 \mathrm{hr}$ & $18 \mathrm{hr}$ & $0 \mathrm{hr}$ & $18 \mathrm{hr}$ \\
\hline Total bacteria & $3 \times 10^{5}$ & $5 \times 10^{8}$ & $4 \times 10^{5}$ & $7 \times 10^{8}$ \\
\hline Coli-form organisms & $2 \times 10^{4}$ & $<10$ & $3 \times 10^{4}$ & $<10$ \\
\hline Egg-Yolk reaction positive Staphylococci & $1 \times 10^{3}$ & $1 \times 10^{8}$ & $1 \times 10^{3}$ & $2 \times 10^{8}$ \\
\hline Egg.Yolk reaction negative Staphylococci & $1 \times 10^{4}$ & $2 \times 10^{8}$ & $2 \times 10^{3}$ & $4 \times 10^{8}$ \\
\hline Enterotoxin (ET) A & ND & 128 & ND & ND \\
\hline B & ND & ND & ND & 32 \\
\hline $\mathrm{C}$ & $\mathrm{ND}$ & ND & ND & 64 \\
\hline $\mathrm{D}$ & ND & 32 & $\mathrm{ND}$ & ND \\
\hline
\end{tabular}

ND: less than $2 \mathrm{ng} / \mathrm{ml}$

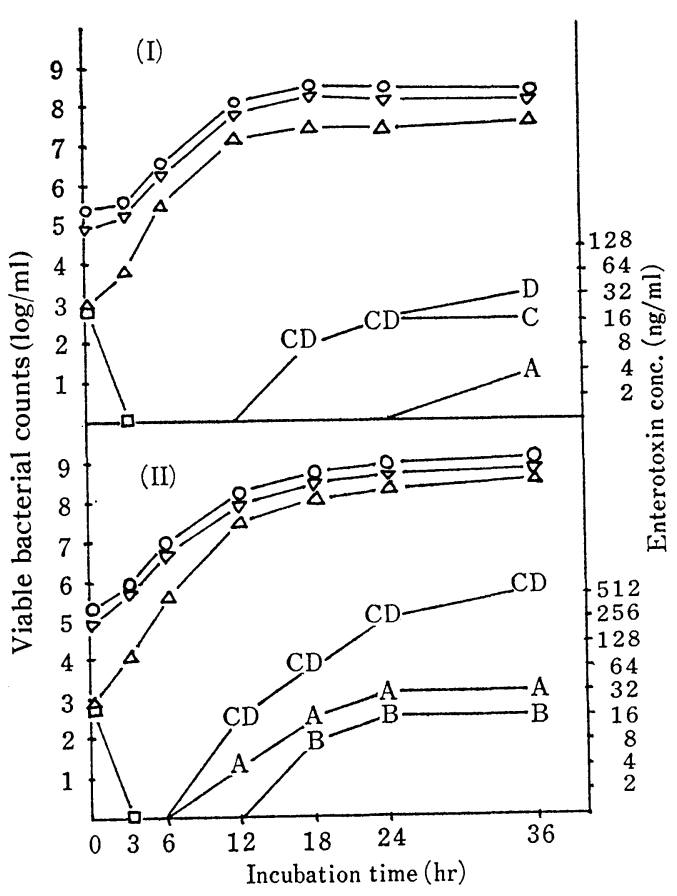

Fig. 1. Growth and enterotoxin production in TLSP broth of $S$. aureus contaminated in raw milk

Culture was done in test tube (I) and in Petri-dish (II) at $37^{\circ} \mathrm{C}$.

Symbols; $\bigcirc$ : total bacteria; $\square$ : coliform organisms; $\triangle$ : Egg-Yolk reaction positive Staphylococci; $\Delta$ : Egg-Yolk reaction negative Staphylococci

A, B, C, D: enterotoxin A, B, C and D

シャーレ内培盖の方が中試験管内培養にくらべ ET
産生が著名に高い傾向は，ロットの異なる他の 2 件の生 乳を用いた実験でも同じ結果が認められた。従って，以 後の実験では培養条件として, シャーレ内で $37^{\circ}, 18$ 時 間静置培養する方法で行った。

次に, 市販の生肉ミンチ及びポテトサラダ各 1 件に, 黄色ブ菌を接種し, 生肉ミンチまたはポテトサラダ中に 含まれる多数の細菌の存在下で, 黄色ブ菌が TLSP ブ イヨン増菌培養により ET を産生するかどらか調べた。

黄色ブ菌接種前の生肉ミンチの生菌数は $5 \times 10^{6} / \mathrm{g}$, 大 腸菌群数は $3 \times 10^{4} / \mathrm{g}$, 卵黄反応陽性黄色ブ菌数は $10^{2} / \mathrm{g}$ 以下，同陰性ブ菌数は $2 \times 10^{4} / \mathrm{g}$ で，これに黄色ブ菌保 存株 F 85 (ET AD 型産生株) を $10^{3} / \mathrm{g}$ になるよらに接 種した。また，ポテトサラダの生菌数は $8 \times 10^{5} / \mathrm{g}$, 大腸 菌群数は $5 \times 10^{4} / \mathrm{g}$, 卵黄反応陽性ブ菌数は $10^{2} / \mathrm{g}$ 以下, 同陰性ブ菌数は $4 \times 10^{3} / \mathrm{g}$ で, これに黄色 ブ菌保存株 F 93 (ET BC 型産生株) を $10^{3} / \mathrm{g}$ になるように接種した. これらの10倍ホモジナイズ液 $10 \mathrm{ml}$ を倍濃度の TLSP ブイヨン $10 \mathrm{ml}$ に加えて, シャーレ内で, $37^{\circ}$ 18時間培 養したときの細菌数と ET 濃度を Table 1 に示した.

市販生肉ミンチ及びポテトサラダを用いて調べた結果 も, 生乳の場合と同様に, 生菌数及び卵黄反応陽性また は陰性ブ菌の急激な増加と大腸菌群の急速な减少が観察 され, 検出された ET は接種した黄色ブ菌の ET 型と 同じであった.

これらの結果から, 黄色ブ菌以外の細菌が多い食品で も, TLSP ブイヨン中で $37^{\circ} ， 18$ 時間程度, シャーレ内 で培養すれば, 被験食品中に含まれた ET 産生黄色ブ菌 の増殖と ET 産生がみられることがわかった。すなわ ち, 被験食品中の ET 産生黄色ブ菌の存在は, 増菌培養 液中に産生された ET の検出により証明できることが 判明した.

前述の方法による $\mathrm{ET}$ 産生黄色ブ菌検索法を, 以後, 検討法と仮称した。 
Table 2. Viable Counts of $S$. aureus by ET-detection Method and by Plate Method

\begin{tabular}{cccc}
\hline \multirow{2}{*}{ Food $^{* 1}$} & $\begin{array}{c}\text { Experiment } \\
\text { No. }\end{array}$ & S. aureus counts $(/ \mathrm{g})$ \\
\cline { 3 - 4 } & 1 & $2.1 \times 10^{2 * 2}$ & Plate method \\
\hline Minced meat & 2 & $2.4 \times 10^{3}$ & $3 \times 10^{2}$ \\
& 3 & $4.3 \times 10^{4}$ & $5 \times 10^{3}$ \\
& 1 & $4.6 \times 10^{2}$ & $8 \times 10^{4}$ \\
\hline Potato salad & 2 & $4.3 \times 10^{4}$ & $8 \times 10^{2}$ \\
& 3 & $1.5 \times 10^{5}$ & $2 \times 10^{4}$ \\
& 1 & $9.3 \times 10^{4}$ & $4 \times 10^{5}$ \\
\hline Raw milk & 2 & $4.3 \times 10^{4}$ & $4 \times 10^{3}$ \\
& 3 & $1.5 \times 10^{5}$ & $9 \times 10^{3}$ \\
\end{tabular}

*1: Minced meat and potato salad were inoculated to adequate amount of $S$. aureus.

*2: MPN values/g

Table 3. Frequency of $S$, aureus Detected by ET-detection Method and by Plate Method

\begin{tabular}{lccc}
\hline \multirow{2}{*}{ Food } & No. of tested & \multicolumn{2}{c}{ No. of positive $(\%)$} \\
\cline { 3 - 4 } & & ET-detection method & Plate method \\
\hline Luncheon & 24 & $5(20.8)$ & $2(8.3)$ \\
Salad & 15 & $3(20.0)$ & $1(6.7)$ \\
Cake & 15 & $2(13.3)$ & $1(6.7)$ \\
Fish meat paste product & 13 & 1 & 0 \\
Frozen food & 4 & 1 & 0 \\
Boiled noodle & 5 & 1 & 0 \\
\hline Total & 76 & $13(17.1)$ & $4(5.3)$ \\
\hline
\end{tabular}

\section{MPN 法による黄色ブ菌数測定への応用}

前回の実験で用いた生肉ミンチ及びポテトサラダに黄 色ブ菌保存株を種々の濃度になるよう接種した被験材料 を調製し，それらに含まれる黄色ブ菌数を，MPN 法に 検討法を応用して求めた值と, 従来通りの平板法で求め た卵黄反応陽性ブ菌数の值を比較した。生肉ミンチには 前記の実験と同様に F 85 株を，ポテトサラダには F 93 株を，それぞれ適当量ずつ添加した被験材料各 3 件につ いてしらべた。また，前記の実験で用いた生乳 3 件につ いても同様に行った. それらの結果を Table 2 に示し た.

生肉ミンチ及びポテトサラダにおける黄色ブ菌数の測 定結果は, 検討法で求めた ET 産生黄色ブ菌数の MPN 值と，平板塗抹法で算定した卵黄反応陽性ブ菌数に大き な差は認められなかった。しかし，生乳の場合には，検 討法で求めた MPN 值の方が, 平板法で求めた卵黄反応 陽性ブ菌数より明らかに多かった。この結果から, 生乳 中には卵黄反応陰性の ET 産生黄色ブ菌が多数含まれ ている可能性が考えられたので，生乳を Baird-Parker 培地に塗抹し, 出現した集落のうち卵黄反応陰性のブ菌 様コロニーについて平板パンチ法により ET 産生性を 検討したところ, 卵黄反応が陰性で ET 及びュアグラー
ゼ産生黄色ブ菌が多数存在することを認めた。

\section{3. 市販食品への応用}

弁当類 24 件, サラダ類 15 件, 和洋生菓子15件, 魚肉水 り製品13件，凍結前未加熱冷凍食品 4 件及びゆでめん 5 件の計76件を対象に検討法の応用を試みた。同時に，卵 黄加マンニット食塩培地を用いた平板法による黄色ブ菌 の検査も実施した。検討法では，検体の10倍ホモジナイ ズ液 $10 \mathrm{ml}$ を増菌培養する方法で, 平板法では同液 0.1 $\mathrm{ml}$ を 2 枚の平板に塗抹培養後, 卵黄反応陽性黄色ブ菌 を検索する方法で調べた.

それぞれの方法による黄色ブ菌検出率を Table 3 に まとめた。

市販食品76件のらち，平板法では 4 件 (5.3\%) から畉 黄反応陽性黄色ブ菌が，検討法では13件 (17.1\%) から ET 産生黄色ブ菌が検出された．前者の方法で卵黄反応 陽性黄色ブ菌が検出された検体は，すべて，後者の方法 で ET 産生黄色ブ菌が検出された。

弁当類 24 件のうち, 検討法で ET 産生黄色ブ菌の存在 が確認された 5 件について，その菌数を前記の MPN 法 で求めた. その結果を平板法での成績とあわせて Table 4 に示した.

検討法で $\mathrm{ET}$ 産生黄色ブ菌が検出された 5 件の弁当 
Table 4. Enumeration of $S$. aureus and Detection of the Enterotoxin by ET-detection Method

\begin{tabular}{lccccc}
\hline \multirow{2}{*}{ Luncheons } & \multicolumn{2}{c}{ ET-detection method } & & \multicolumn{2}{c}{ Plate method } \\
\cline { 2 - 3 } \cline { 5 - 6 } & S. aureus counts (MPN/g) & Detected ET & & S. aureus counts $(/ g)$ & $\begin{array}{c}\text { Et type of } \\
\text { strain }\end{array}$ \\
\hline Rice ball & $4.3 \times 10^{2}$ & $\mathrm{AC}$ & & $7 \times 10^{2}$ & $\mathrm{AC}$ \\
Maki-zushi & $9.1 \times 10$ & $\mathrm{~A}$ & & $<10^{2}$ & $\mathrm{BC}$ \\
Inari-zushi & $9.3 \times 10^{2}$ & $\mathrm{ACD}$ & & not detectable* \\
Chirashi-zushi & $4.3 \times 10^{3}$ & $\mathrm{BC}$ & & $2 \times 10^{3}$ & $\mathrm{BC}$ \\
Kashiwa-meshi & $7.3 \times 10$ & $\mathrm{C}$ & $<10^{2}$ & \\
\hline
\end{tabular}

* $S$. aureus was not detectable by interference with many Bacilli colonies.

類のらち, 2 件は平板法でも卵黄反応陽性黄色ブ菌が検 出され, その菌数に差はなかった. 平板法で検出された 卵黄反応陽性黄色ブ菌の ET 型は検討法の培養液から 検出された ET 型に一致した。

検討法で ET 産生黄色ブ菌の存在が証明されたにも かかわらず，平板法で卵黄反応陽性黄色ブ菌が認められ なかった 3 件のうち 2 件は, その菌数が $1 \mathrm{~g}$ 当り $10^{2}$ 以 下であった. 他の 1 件は, 平板法では Bacillus 属と思 われる細菌のコロニーが多数出現して卵黄反応陽性黄色 ブ菌コロニーが見出せなかった。

\section{考察}

ブ菌食中毒は，黄色ブ菌が食品中で産生した ET を摂 取することにより発生する. 従って, 食品衛生上, 問題 となるブ菌は ET 産生性黄色ブ菌である.

現行の黄色ブ菌検査法 ${ }^{1)}$ は, 卵黄反応陽性のコアグラ 一ゼ産生ブ菌を対象としているため, 卵黄反応陰性もし くはコアグラーゼ微弱産生の ET 産生黄色ブ菌は見落 される可能性が高い。畜産食品由来の黄色ブ菌に卵黄反 応陰性株が多いといら報告5),6) や，例数は少ないが，二 アグラーゼ㓌性ブ菌による食中毒例 ${ }^{7)}$ (8) があることを考 えると, 食中毒原性黄色ブ菌検査の指標として, 卵黄反 応やュアグラーゼ産生能は不十分と思われる。

また, 従来の黄色ブ菌検査の問題点として, 食品の種 類によっては, 平板培地上に黄色ブ菌以外の細菌が多数 生育して, 黄色ブ菌検索に支障をきたす場合があること や，病人食や乳幼児向食品などの厳しい衛生度が望まれ る食品では微量の黄色ブ菌が検出できない点や, 検査に 時間がかかる点などいくつかの欠点が指摘される.

今回著者が検討した食中毒原性黄色ブ菌検索法は, 食 品などを黄色ブ菌の選択増菌培地中で比較的短時間培養 し, 被検食品中に ET 産生黄色ブ菌が存在した場合に のみ培養液中に産生されてくる ETを検出することによ り，食中毒原性黄色ブ菌検索を行うもので，ET 産生性 を検査の指標としているため，前記のような欠点はみら れない。ただしこの方法では，ET 産生黄色ブ菌が存 在した場合に必らず培養液中に ET が産生されること が前提であり，用いる増菌培地は重要といえる.
ここで用いた黄色ブ菌選択増菌培地は，ET 産生促進 作用が著明 ${ }^{9)}$ な可溶性デンプンとピルビン酸塩を加えた ブイヨンを基礎培地に，選択抑制剤として，BairdParker 培地に使用されている亜テルル酸カリウムと塩 化リチウムを加えた試作培地である，本培地は，高濃度 食塩を選択抑制剂に用いた場合にみられる ${ }^{10)} \mathrm{ET}$ 産生 抑制がなく，ほぼ所期の目的に適したものであった。し かし，選択性がやや弱い点や保存性に欠ける点などは， 今後さらに改良の余地があろう。

培養条件で，試験管内培養よりシャーレを用いた水平 培養の方が ET 産生が著明に高かったが，その理由は， 好気的条件で ET 産生が促進されるためと考えられる。 シャーレ内培養では, $37^{\circ}, 18$ 時間で検出に必要な ET 濃度が十分に産生され，RPLA 法による ET 検出に要 する時間とあわせても, 約30時間後には結果が得られ, 従来法よりかなり迅速であった. 振とう培養法の併用 や，增菌培地の改良，ET 検出時間の短縮 (RPHA 法を 用いるなど）により，検査に要する時間はさらに短縮で きると考える。

市販食品に検討法を応用したところ, 従来法では卵黄 反応陽性黄色ブ菌が検出されなかった多数の検体から $\mathrm{ET}$ 産生黄色ブ菌が検出された.このことは, 微量の黄 色ブ菌もしくは, 畉黄反応陰性などの理由で従来法では 検出されない黄色ブ菌に污染された市販食品がかなり存 在することを示しており，保存条件によっては食中毒を 起こす危険性も考えられる.

ブ菌食中毒は，我が国で年間 200 件以上発生してお り, 近年は増加傾向がみられる. 食中毒防止に, 今後は 前述のような危険性をも対象とした厳しい監視行政と, 製造者側の品質管理体制が必要と思われる.

\section{まとめ}

食中毒原性黄色ブ菌の食品からの検査法として, 被験 材料を選択増菌培地中で増菌させ, 培養液中に産生され たエンテロトキシン $(\mathrm{ET})$ を検出することにより， ET 産生黄色ブ菌の存在を証明する簡易検索法について検討 した。

1. ET 産生用選択増菌培地として試作した Tellu- 
lite-Lithium-Starch-Pyruvate (TLSP) ブイョンは, 黄色ブ菌以外の細菌が多い食品に対しても, 黄色ブ菌の 選択的増菌と ET 産生にほぼ適していた。また，そのと きの培養条件は，シャーレを用いた水平培養の方が，試 験管での垂直培養よりも ET 産生が良好であった。

2. この方法を MPN 法に応用することにより，ET 産生黄色ブ菌の定量が可能であった。

3. この方法を市販食品に応用したところ, 平板法で は黄色ブ菌が検出されなかった検体より ET 産生黄色 ブ菌が検出された例が多数見出された．その理由は，本 法では, 食品中に含まれる少数の ET 産生黄色ブ菌はも とより卵黄反応陰性あるいはコアグラーゼ陰性で ET 産生性の黄色ブ菌の検出が可能なためである。

\section{謝 辞}

SET-RPLA キットを恵与して頂いたデンカ生研 (株) 杉山純一氏に感謝いたします。

文献

1）厚生省環境衛生局監修: “食品衛生検查指針 I” p. 87 138（1973）（社）日本食品衛生協会，
2）寺山 武：モダンメディア， 27， 470～482 (1980).

3）小田隆弘：食衛誌. 26，29～32（1985）.

4）小田隆弘，大久保忠敬，永井 誠，西本幸一，大 丸健之助：福岡市衛試報．4，33３7 (1979).

5) Hájek, V.: Appl. Environ. Microbiol. 35, 264 268 (1978).

6) Takeshige, K., Watanabe, K., Igarashi, H., Shingaki, M., Terayama, T.: Jpn. J. Vet. Sci. 45, 355 362 (1983).

7) Breckinridge, J. C., Bergdoll, M. S.: The New Engl. J. Med. 284, 541 543 (1971).

8）森 正司, 安形則雄, 野村 寛, 土平一義：名古 屋市衛研報。29，43４5（1982）。

9）小田隆弘, 永井 誠, 大久保忠敬, 西本幸一, 北 原郁也：福岡市衛試報。5，81９5（1980）。

10)五十嵐英夫, 新垣正夫, 山田澄夫, 潮田 弘, 寺 山 武, 坂井千三: 東京都衛研年報. 29-1, 6 12 (1978). 